\title{
A RIMANÓCZY ÉPÍTÉSZDINASZTIA TÖRTÉNETE (I. rész)
}

\section{A NAGYVÁRAdI ÁG}

RIMANÓCZY JENÖ* - FERKAI ANDRÁS**

*Ybl-díjas építészmérnök, nyugdíjas. 1123 Budapest, Nagyenyed utca 7. Tel.: (+36-30) 440-3436. E-mail: rimanoczy.jeno@chello.hu

**DSc, egyetemi tanár. Moholy-Nagy Művészeti Egyetem, Design- és Mủvészettörténeti Tanszék, 1121 Budapest, Zugligeti út 9-25. Ideiglenes cím: 1111 Budapest, Bertalan Lajos utca 2. I. emelet 106.

Tel.: (+36-1) 392-1157. E-mail: ferkai@mome.hu

A többgenerációs építészdinasztiák közül is kiemelkedik a Rimanóczy család, amely a kiegyezéstöl a rendszerváltásig négy nemzedéken át járult hozzá kiváló szakemberek munkásságával a magyar építészet történetéhez. Idősebb Rimanóczy Kálmán építőmester és a berlini Mủegyetemen végzett építész fia, ifjabb Kálmán Nagyváradon müködött abban a 19. század végi és 20. század eleji időszakban, amikor a partiumi város rohamos ütemben modernizálódott, s mindketten jelentős épületekkel járultak hozzá a település gyökeres átalakulásához. Idősebb Kálmán elsőszülött fia, Árpád, aki a katonai pályát választva fordult a mérnöki hivatás felé, Budapesten dolgozott a Honvédség építési osztályán. Legidősebb gyermeke, Gyula vitte tovább a szakmát, s kétségtelenül az ő húszas évektől az ötvenes évekig ívelő életmüve számít a családból a legismertebbnek. Két fia, ifjabb Gyula és Jenő választotta az építész hivatást, az ő müködésük már szinte teljesen az állami tervezés időszakára esik. Az építészdinasztia történetét Rimanóczy Jenő állította össze a családban megőrzött dokumentumokra, emlékekre és publikációkra alapozva, $\mathrm{s}$ adja közre három részben, hogy megvilágítsa a kevésbé ismert részleteket, $\mathrm{s}$ alapanyagot nyújtson a régóta esedékes monográfiák megírásához.

Kulcsszavak: Rimanóczy-dinasztia, építészettörténet, 19-20. század, Nagyvárad, Budapest

\section{BEVEZETÉS}

A magyar építészet történetében nem ritka a több generációt átívelő építészdinasztia. A 19. század első felében fontos szerepet játszottak a Hild, Brein, Kasselik, Zitterbarth famíliák, később a Bobula, Gregersen vagy a Giergl-Györgyi család, a 20. században pedig többek között a Janákyak, vagy a negyedik nemzedéknél tartó Vadász család. Ebben a széles merítésben is kiemelkedő a Rimanóczy építészdinasztia, melynek története százötven éve, valamikor a kiegyezés környékén kezdődött, amikor id. Rimanóczy Kálmán Nagyváradra érkezett. A családfát egészen a 17. századig lehet visszavezetni, az első ismert dokumentum az a címeres nemeslevél, melyet III. Ferdinánd király adományozott 1646. május 26-án Pozsonyban Rimanóczy János fraknói várnagynak és Miklós nevü testvérének, és amelyet Sopron vármegye hirdetett ki. Kálmán édesapja, Rimanóczy József Sámuel (1803-1870) Kismartonban született, előbb a közeli Kapuváron, majd később Kaposváron élt és Nagyváradon halt meg. Kálmán Kapuváron született, és tőle származik a család nagyváradi, illetve 


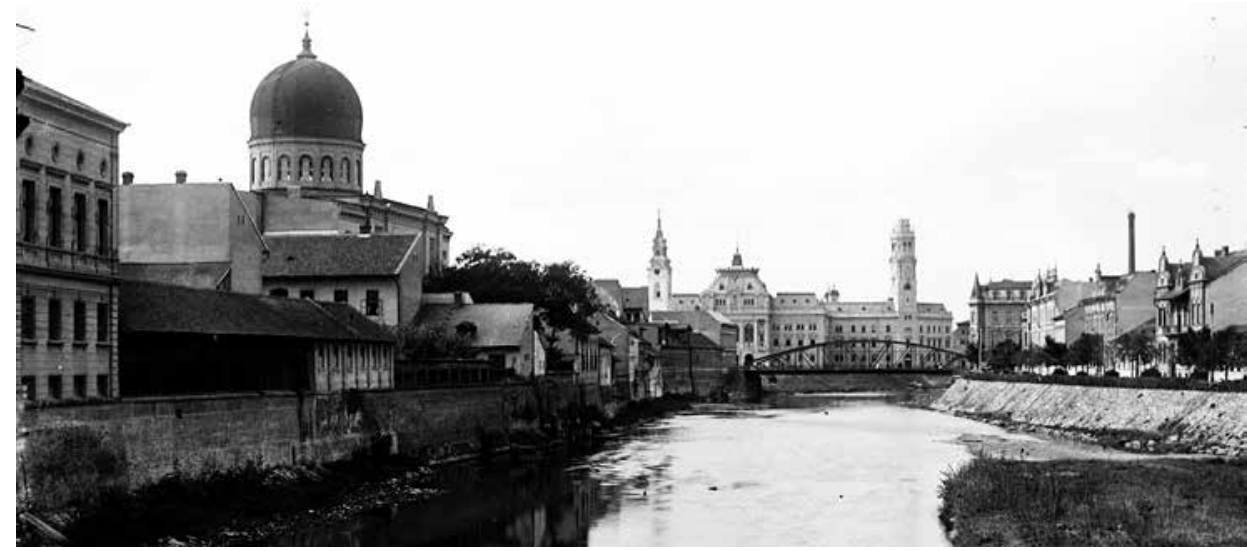

1. ábra. Nagyvárad központjának képe 1907-ben a Körössel. Balra a neológ zsinagóga kupolája, háttérben a Városháza, a hídtól jobbra a Rimanóczy-fürdő, távolabb a Rimanóczy-bérház (Fortepan 86866. Magyar Földrajzi Múzeum - Erdélyi Mór cége)

budapesti ága. Építőmesterként, tervezéssel és kivitelezéssel egyaránt foglalkozó vállalkozóként komoly szerepe volt Nagyvárad urbanizálásában, számos fontos épület tervezése vagy megvalósítása füződik a nevéhez (1. ábra).

Az építész szakmát Nagyváradon született második fia - az elsőről később szólunk -, ifj. Rimanóczy Kálmán folytatta, aki Németországban szerzett építész diplomát és Budapesten építőmesteri képesítést. Rövid munkássága alatt - hiszen összesen negyvenkét évet élt - növelte az apja által szerzett vagyont és a Rimanóczy név ismertségét, már nemcsak Nagyváradon, hanem az akkori Magyarország egyéb területein is. Három gyermeke volt, de közülük egyik sem folytatta apja hivatását. A nagyváradi ágon így építész nem követte az első világháború előtt meghalt idősebb és ifjabb Rimanóczy Kálmánt. A szakma ezután a budapesti ágon öröklődött tovább.

Most kell szót ejtenünk idősebb Kálmán elsőszülött fiáról, Árpádról, akit édesapja ugyan vállalt, mégis anyja és annak második férje, Rimanóczy Károly nevelt fel. Árpád a katonai pályát választotta, $\mathrm{s}$ a bécsi katonai építőmérnöki tanfolyamot elvégezve lett végül építész. Mérnökkari ezredesként vonult nyugdíjba. Három gyermekéből Gyula fia folytatta a szakmát $\mathrm{s}$ hozott létre a két világháború között, illetve 1945 után igen jelentős életművet. Az ő szintén három gyermeke közül a két fiú követte példáját. Ifjabb Gyula és Jenő, a Műegyetemet elvégezve, az állami tervezésben (a Buvátiban, illetve az Ipartervben) talált munkát, de indulásukkor még módjuk volt édesapjukkal, a KÖZTI müteremvezetőjével együtt dolgozni néhány tervpályázaton.

Sajnos eddig egyik Rimanóczy munkásságáról sem készült átfogó monográfia, bár a nagyváradi ág feldolgozása megkezdődött, és Rimanóczy Gyula kiállításához annak idején katalógus készült. Ennek a tanulmánysorozatnak az a célja, hogy a megmaradt dokumentumokra, a családi emlékezetre és a publikációkra támaszkodva 
közreadja mindazt, amit a Rimanóczy-dinasztiáról ma tudni lehet, ezzel is segítve azok munkáját, akik - remélhetően hamarosan - egy-egy alapos, elemző monográfia megírására vállalkoznak.

Rimanóczy Jenö

Örömmel tettem eleget Rimanóczy Jenő kérésének, hogy a Rimanóczy építészdinasztiáról összeállított írását sajtó alá rendezzem. Feladatomnak a szöveg szerkesztését, az adatok ellenőrzését és kiegészítését, a művek listájának gondozását, a jegyzetapparátus és irodalomjegyzék formába öntését tekintettem.

Ferkai András

\section{IDÖSEBB RIMANÓCZY KÁLMÁN (1840. MÁJUS 12. - 1908. JANUÁR 2. $)^{1}$}

„Szent jelkép ez a név: Rimanóczy. A munka és az emberszeretet jelképe.” Nagy Márton ${ }^{2}$

Nagyvárad neves építője Kapuváron született, Rimanóczy József Sámuel (18031870) és Kiszelényi Franciska (1810-1870) ötödik gyermekeként, ahol édesapja az Esterházy család uradalmának ispánja volt. Hamarosan a kismartoni hercegi család egy másik birtokára, Kaposvárra helyezték át, s a sokgyermekes család feje ott Kálmán fiát iparos pályára adta. Tizenkét évesen állt be egy kőmüves mester mellé inasnak, és kitanulta a szakmát. Mestereinek korán feltünt kitünő rajzkészsége, ezért javaslatukra Budára vándorolt, ahol Koczka Nándor ${ }^{3}$ építési vállalkozónál dolgozott. Később Szolnokon müködött mint építésvezető. Ezután minden bizonnyal építőmesteri vizsgát tett, amely nemcsak kivitelezésre, hanem tervezésre is feljogosította (2. ábra). Önálló működését Pest-Budán kezdte meg, ott ismerkedett össze egy Gömöry Hermina nevü fiatalasszonnyal, aki talán éppen miatta költözött külön férjétől. Kapcsolatukból 1867. április 11-én fiúgyermek született, aki a keresztségben az Eduárd Árpád nevet kapta. Amikor azonban Kálmán meghívást kapott Nogáll János $^{4}$ nagyváradi kanonoktól, a későbbi püspöktől az árva gyerekek otthonának szánt váradi Szent Vince Intézet építésére, otthagyta családját, s az asszony visszament férjéhez, aki adoptálta a gyermeket.

\footnotetext{
${ }^{1}$ A nagyváradi Rimanóczyakról szóló fejezetek adatai alapvetően helyi történészek publikációin alapulnak, e tekintetben föként Jósa 2008 és Péter 2013 szolgált forrásként.

${ }^{2}$ A Nagy Márton írói álnév. Valódi neve: B. Endrődy Károly. (Nagyvárad, 1860. augusztus 29. - Nagyvárad, 1941. augusztus 15.) Erdélyi magyar író, szerkesztő, publicista, főszolgabíró. Az idézet A Rimanóczyak Nagyváradon címü, Péter I. Zoltán könyvét ismertető cikkből való. Biharország (2013) 7.

${ }^{3}$ Koczka Nándor építőmester, építész Szolnokon, de Budapesten is dolgozott a 19. század második felében.

${ }^{4}$ Nogáll János (Győr, 1820. június 24. - Nagyvárad, 1899. július 19.) egyházi hitszónok és bölcseletkari hittanár, nagyprépost, fölszentelt püspök, Nagyvárad díszpolgára.
} 


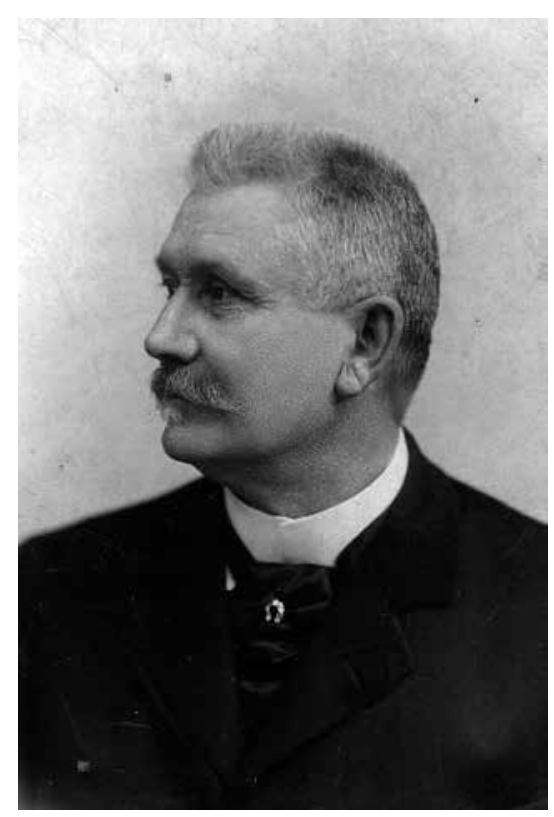

2. ábra. Idősebb Rimanóczy Kálmán arcképe (Rimanóczy Jenő gyüjteménye)

Nogáll régi ismerőse lehetett az építésznek és családjának, hiszen a kanonok apja is az Esterházy uradalom alkalmazottja volt. Kálmán neki köszönhette első munkáit, többek között a Páli Szent Vince Irgalmas Nővérek Rendjének Ferdinánd (későbbi Nogáll) utcában lévő házának tervezését és kivitelezését, melyek segítették megtelepedését, illetve pályakezdését az akkoriban gyors fejlődésnek indult városban. Hamarosan hírnevet szerzett magának Nagyváradon olyan fontos középületek kivitelezésével, mint például a Neológ zsinagóga, vagy a Szigligeti Színház. Később a vállalkozás mellett tervezett is, mégpedig igen sokfajta épületet: lakóházat, pénzintézetet, kaszinót, kereskedelmi épületeket, múzeumot és laktanyát. Saját beruházásban épített szállodát és fürdőt a Körös partján, és bérpalotát a Fő utcában. Találmányai és szabadalmai voltak, ipari épületek és gyárkémények építőjeként komoly bevételre tett szert, melyből 1885-ben tégla-, cserép- és kályhagyárat létesített Váradon. Távoli városokba (Triest) is meghívták ipari építkezések lebonyolítására. A négy nyelvet beszélö, világlátott és müvelt szakember országosan elismert tekintélynek számított. A századfordulóra Nagyvárad egyik legbefolyásosabb és leggazdagabb embere lett. Nem csak Váradon voltak ingatlanai, a fővárosban ô építtette Kerepesi (ma Rákóczi) úti telkére Schmahl Henrik tervei alapján a budapesti Urániapalotát (1893-1896). 1875-ben meghívták a szinajai királyi nyaraló kastély kivitelezésének versenytárgyalására is. Id. Rimanóczy Kálmán 1894-től az Áldás utca (később Rimanóczy utca, ma Strada Josif Vulcan) 5. szám alatt lakott a maga tervezte és kivitelezte emeletes házban, majd 1905-ben beköltözött a fia által pazar velencei 
gót stílusban tervezett kétemeletes palotájába a Széchenyi tér és a Fő utca sarkán. A város környékén szőlőbirtokai voltak, $\mathrm{s}$ a nagyváradi szőlőbirtokosok hegyi választmánya 1888-ban többek között Rimanóczy borát kóstolva győződhetett meg arról, hogy „,a váradi szőlőtalaj veres borok termelésére kiválóan alkalmas, s ily borok a többi hazai borokkal a versenyt bátran kiállják". 5

Szüleit már letelepedése után nem sokkal Váradra hívta és saját maga is családot alapított. Egy félárva lányt - Kápolnai Vilmát - vett el. Rövidesen megszületett első gyermekük, ifjabb Kálmán, aki ugyancsak az építész szakmát választotta. Három évvel később követte a házaspár második fiúgyermeke, Béla (később belőle is mérnök lett). Nem sokkal ezután Kápolnai Vilma betegeskedni kezdett, s mivel állandó kezelésre és felügyeletre szorult, férje gyakorlatilag egyedül nevelte két fiát. $\mathrm{Az}$ asszony 1901. június 1-jén a Lipótmezői klinikán hunyt el. Időközben az apa elsőszülött fia, Árpád is Nagyváradra került, ezt bizonyítja id. Rimanóczy Kálmánnak az a képeslapja, amelyet 1889-ben a párizsi világkiállításról címzett Váradra az immár huszonkét éves fiának, de a levél lényegében mindhárom fiának szólt. Felesége halála után, 1901. augusztus 18-án újra megházasodott, egybekelt az akkor 21 éves Fehér Erzsébettel. Árpád fiát, mivel kifogásolta gyors újraházasodását és a nagy korkülönbséget, az apa ekkor kitagadta. Harmadik házasságát követően, egy ideig Kálmán fia is az ő irodájában munkálkodott, vezette édesapja kivitelezési munkálatait, de később önállósította magát. Id. Rimanóczy Kálmán virilistaként, azaz olyan polgárként, aki jövedelme után a legtöbb adót fizette be a város kasszájába, szinte haláláig tagja volt Nagyvárad város törvényhatósági képviseletének. 1879-ben tagja lett a nagyváradi László király szabadkőmüves páholynak. Számos jótékony tett füződik a nevéhez: a városi vízmü és vízvezeték-hálózat építését például $15000 \mathrm{Ft}$ értékü telkének felajánlásával segítette, ${ }^{6}$ és nagyrészt neki volt köszönhetö, hogy a Bémer téren felépülhetett a város állandó színháza. A régóta érlelődő álom megvalósítását ő tette lehetővé azzal, hogy a színház telke mellett felépített Bazárépület tízéves bérjövedelmét felajánlotta a színház építésének és müködtetésének fedezésére, azzal a kitétellel, hogy ha a bevétel nem érné el az évi 20000 forintot, akkor azt saját vagyonából kiegészíti. ${ }^{7}$

Hatvanötödik életéve betöltése után egyre gyakrabban betegeskedett, ettöl kezdve teljesen visszavonult a közéleti szerepléstöl, 1908. január 2-án halt meg. Végrendelete általános érdeklődést váltott ki, mivel annak felbontása előtt már lehetett tudni, hogy az elhunyt impozáns összeget juttat vagyonából Nagyvárad városának. A végrendelet vonatkozó része így szólt: „Nagyvárad városának örök tulajdonjoggal hagyományozom a Mészáros utcára és Ezredévi emléktérre, valamint a Bémer térre néző, nevemet viselő fürdőt és szállodát az ehhez tartozó Royal kávéház-épülettel együtt. Óhajtom, hogy a nemes város ezen fürdö-szállodát örök időkre tulajdonában tartsa, $\mathrm{s}$ ez örök időkre nevemet viselje. Az épületben levő felszerelések és ingóságok mind a város

\footnotetext{
${ }^{5}$ Borászati Lapok 20 (1888) 4. 23.

${ }^{6}$ Pesti Hirlap 1892. december 16.

${ }^{7}$ Pesti Napló 1899. május 28.
} 
tulajdonába mennek át... Óhajtom, hogy Nagyvárad városa a neki hagyományozott vagyon jövedelmét a szegényügy rendezésére fordítsa. Osszon ki évenként a szegények között 3000-4000 koronát, a többit tőkésítse, amit a szegényügy nagyobb föllendítésére fordítson. Például dologházzal egybekötött szegényház, hajléktalanoknak lakás, télen melegítők, kenyérosztók, stb. Nem részletezem, a város bölcsességére bízom." " A feltételekböl később azonban nem sokat tartottak be, különösen a Ceauşescu-korszakban, amikor a szálloda nevét Sebes-Körösre (Crişul Repede) változtatták, illetve amikor a rendszerváltás után a külön privatizált fürdőszárnyat bankfiókká alakították át. A szegényeknek pedig 1908 és 1945 között is vajmi kevés jutott a fürdő és szálló bevételéből.

\section{IDŐSEBB RIMANÓCZY KÁLMÁN AZONOSÍTHATÓ MUNKÁI}

\section{AZ ÁLTALA TERVEZETT ÉS KIVITELEZETT ÉPÜLETEK}

- Szent Vince Intézet. Nagyvárad, Nogáll utca 5. (ma Strada Partenie Cosma). Romantikus stílusú. A földszintes (középső) szárny: 1868.

- Honvédlaktanya (ma Hadkiegészítő Parancsnokság). Nagyvárad, Barátok utcája, később Sal Ferenc utca 2. (ma Strada Dunărea). 1882. Historizáló (egyszerü neoreneszánsz) stílusú. 1892-ben bővítés.

- A Körös-parti református templom tornya. Nagyvárad, Ezredévi emléktér 40. (ma Piaţa Liberătii). 1884. Neobarokk stílusú.

- Az evangélikus egyház parókiája. Nagyvárad, Körös utca 28. (ma Strada Tudor Vladimirescu). 1885. Historizáló stílusú.

- A Bihar Megyei Kereskedelmi, Ipar és Termény Hitelbank székháza (ma a polgármesteri hivatal étterme). Nagyvárad, Teleki utca 3. (ma Strada Primăriei). 1886. Historizáló (neoreneszánsz) stílusú.

- Gróf Plater Syberg Mihály vadászkastélya, Kimpány (ma Cîmpani, Bihar megye). 1886 körül.

- A Nagyváradi Takarékpénztár székházának átépítése. Nagyvárad, a Teleki utca 2. (ma Strada Primăriei) és a Szent László tér (ma Piața Unirii) sarkán. 1887. Historizáló (neoreneszánsz) stílusú.

- Római Katolikus Papnevelde bővítése. Nagyvárad, Pray György utca 7. (ma Strada Berzei). 1888.

- A Bihar Megyei Nemzeti Kaszinó székháza (ma az Ady Endre középiskola része). Nagyvárad, Úri utca 2. (ma Strada Ciorogariu). 1888. Historizáló (színvonalas neoreneszánsz) stílusú (3. ábra).

- Deutsch-ház (ma irodaház). Nagyvárad, Zöldfa utca 2. (ma Strada Vasile Alecsandri) és a Szent László tér (ma Piața Unirii) sarkán. 1888. Historizáló (igényes neoreneszánsz) stílusú. 


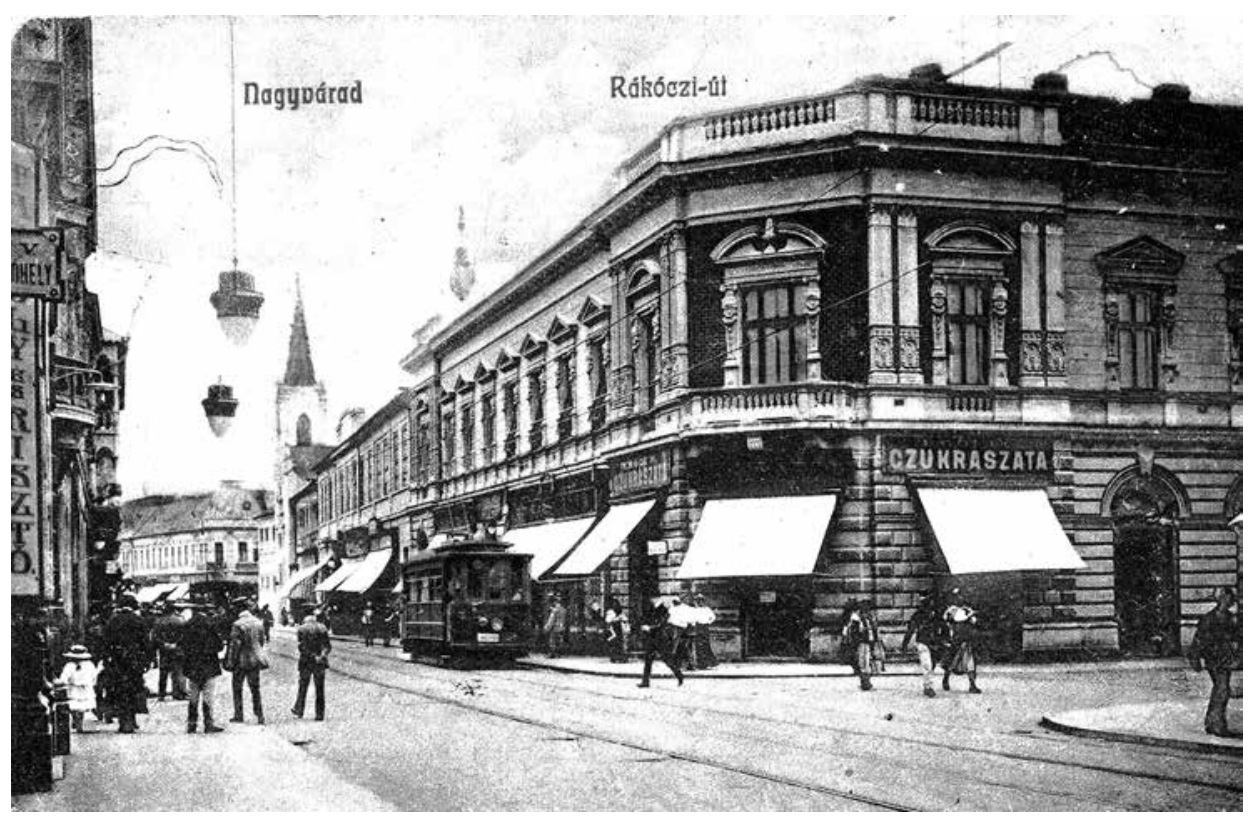

3. ábra. Bihar Megyei Nemzeti Kaszinó, Nagyvárad, 1888 (képeslap)

- Eleméry-ház. Nagyvárad, Nagysándor József utca 4. (ma Strada Aurel Lazăr). 1889. Historizáló stílusú. Ma minden díszétől megfosztott épület.

- Gyógyépület, később kaszinó, Püspökfürdő. 1890. Historizáló stílusú.

- Rimanóczy Szálloda és Gőzfürdő (ma Crişul Repede szálloda). Nagyvárad, Ezredévi emléktér 8. (ma Piaţa Libertătii). Mészáros Lázár utca 2-4. (ma Nicolae Grigorescu) és Bémer tér (ma Piaţa Regele Ferdinand I.). 1892. Historizáló (neobarokk) stílusú, a Royal Kávéház belseje szecessziós (4-5. ábra). A Bémer téri szárny később, 1900 öszére épült fel. A privatizált épület évek óta használaton kívül romlik, 2017 márciusában határozott a Bihar megyei önkormányzat, hogy elővásárlási jogával élve megvásárolja a müemlékegyüttes Bémer térre néző szárnyát.

- Andrényi-féle vasáruház. Nagyvárad, Nagypiacz, később Nagyvásár tér 4-6. (ma Piaţa 1. Decembrie). 1893. Historizáló (gazdag neoreneszánsz) stílusú.

- Szent László-szobor talapzata és építészeti kerete. 1893. Szobrász: Tóth István. Tervezés és kivitelezés. Ma a Szent László-bazilika előtt (Kanonok sor), eredetileg a Fő tér (Szent László tér) közepén volt.

- Rimanóczy-féle egyemeletes ház. Nagyvárad, Ezredévi emléktér 14. (ma Piaţa Libertătii). 1894. Historizáló (neobarokk) stílusú.

- Rimanóczy-féle kétemeletes ház. Nagyvárad, Áldás (később Rimanóczy Kálmán utca, majd Strada Josif Vulcan) utca 5. 1894. Historizáló (neobarokk) stílusú.

- Múzeum (ma Gyermekpalota). Nagyvárad, Múzeum utca 2. (ma Strada Muzeului). 1895. Historizáló (neoreneszánsz) stílusú (6. ábra). 


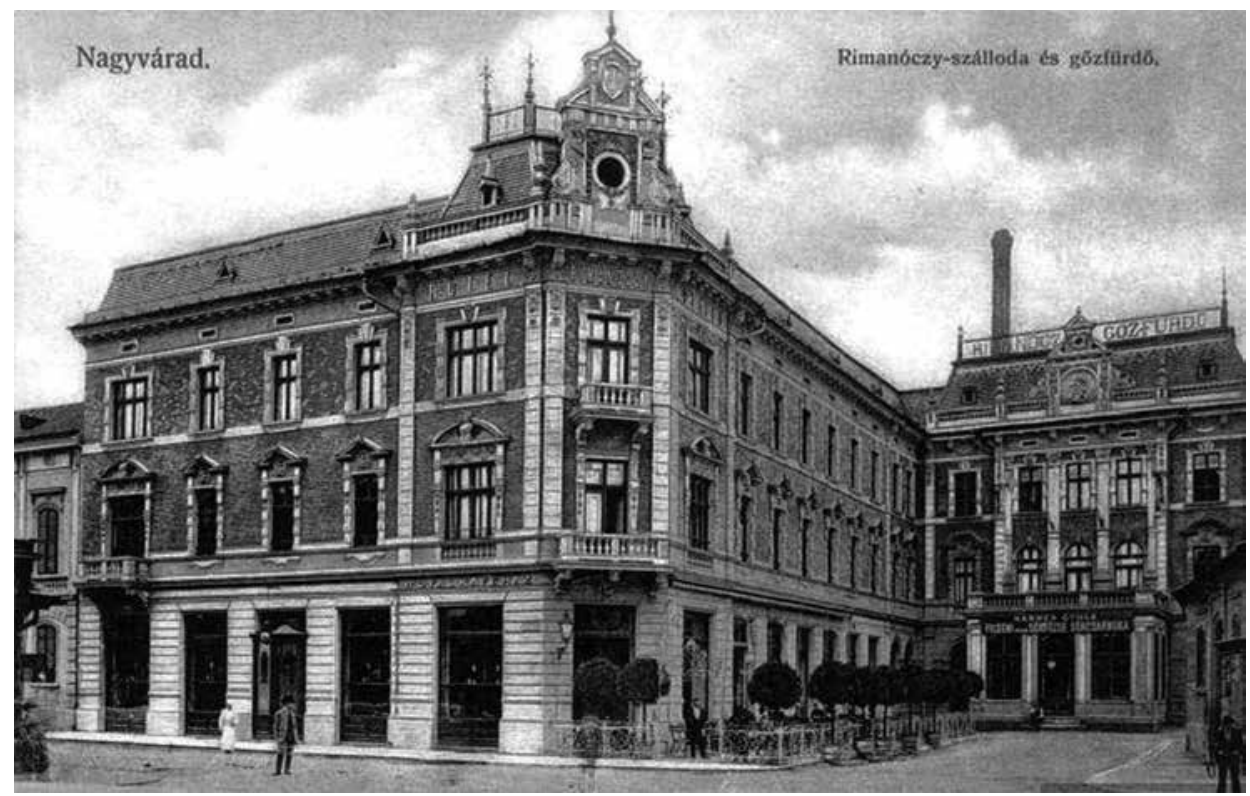

4. ábra. A Rimanóczy-szálló és Gőzfürdő, 1892-1900 (képeslap)

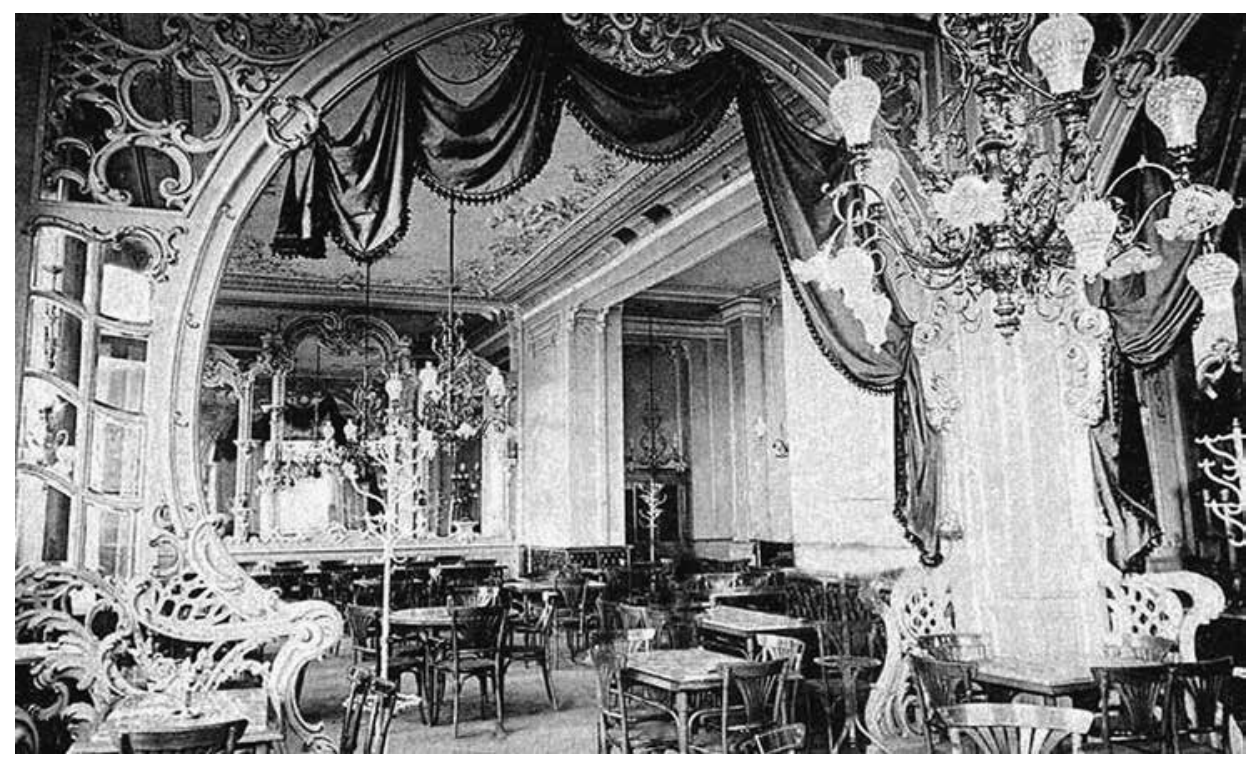

5. ábra. A Royal-kávéház belseje, 1900 (képeslap) 


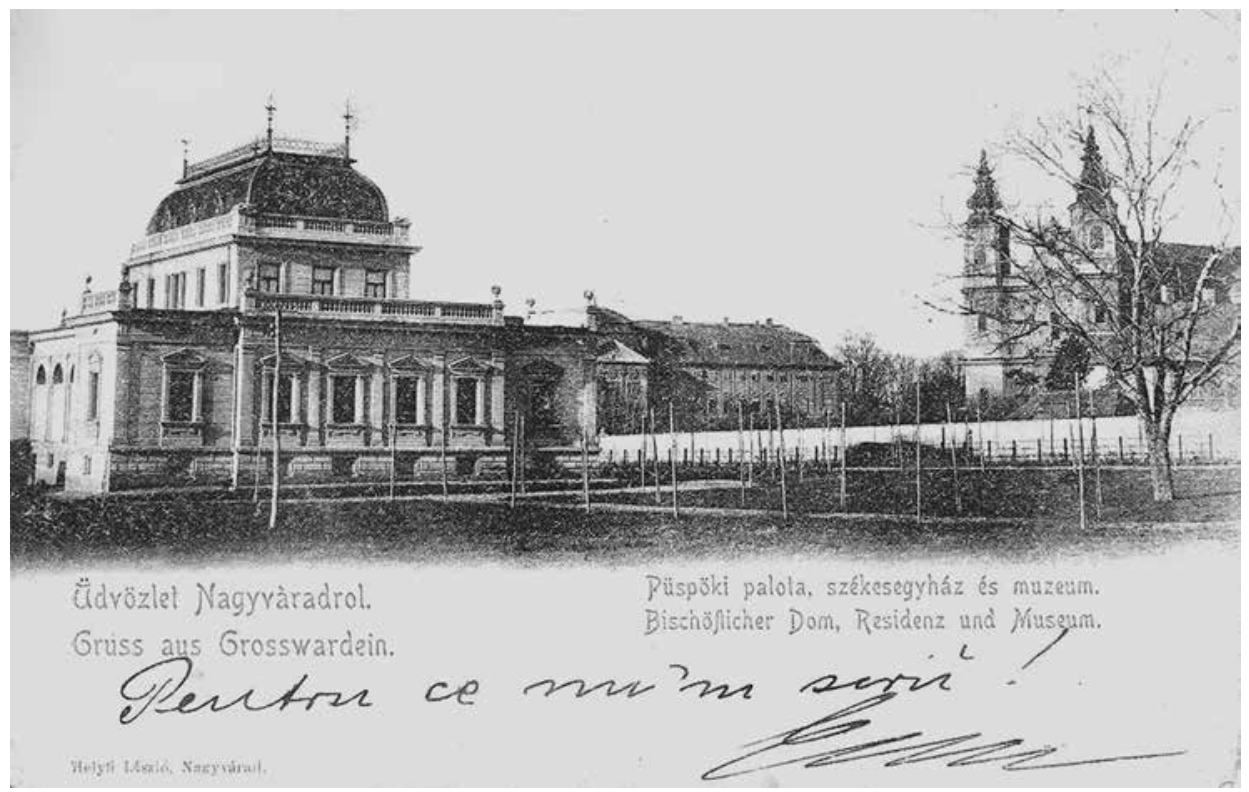

6. ábra. Múzeum, Nagyvárad, 1895 (képeslap)

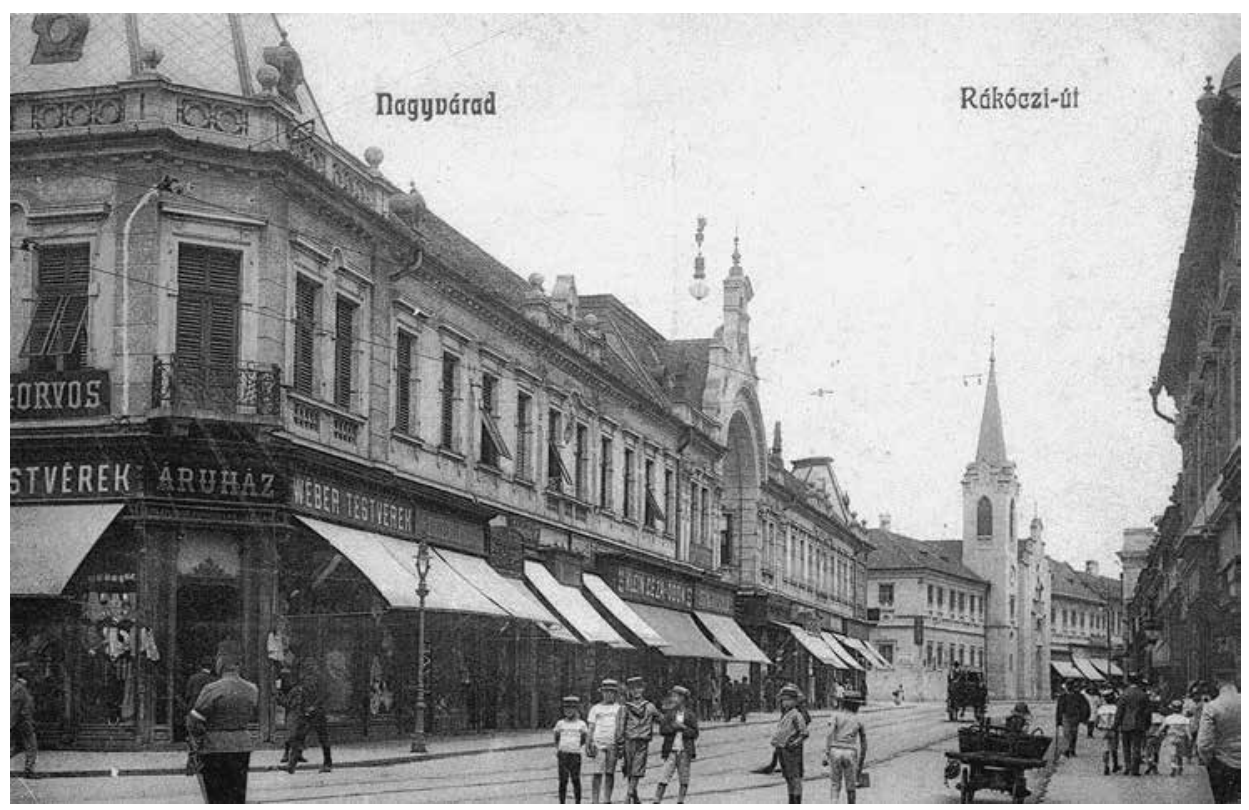

7. ábra. Bazárépület, Nagyvárad, 1900 (képeslap) 
- Kápolna a Szent Vince Intézet udvarán. Nagyvárad, 1896. Historizáló (romantikus) stílusú. Az épületet lebontották.

- Bazárépület. Nagyvárad, Madách utca (ma Strada Madách Imre) és Fő utca (Calea Republicii) között. 1900. Historizáló (neobarokk) stílusú (7. ábra).

- A 4. honvéd gyalogezred kaszárnyája (ma NATO HUMIN Centre). Nagyvárad, Rulikowski Kázmér út 24. (ma Calea Armatei Romãne). 1902. Egyszerü, historizáló stílusú (8. ábra).

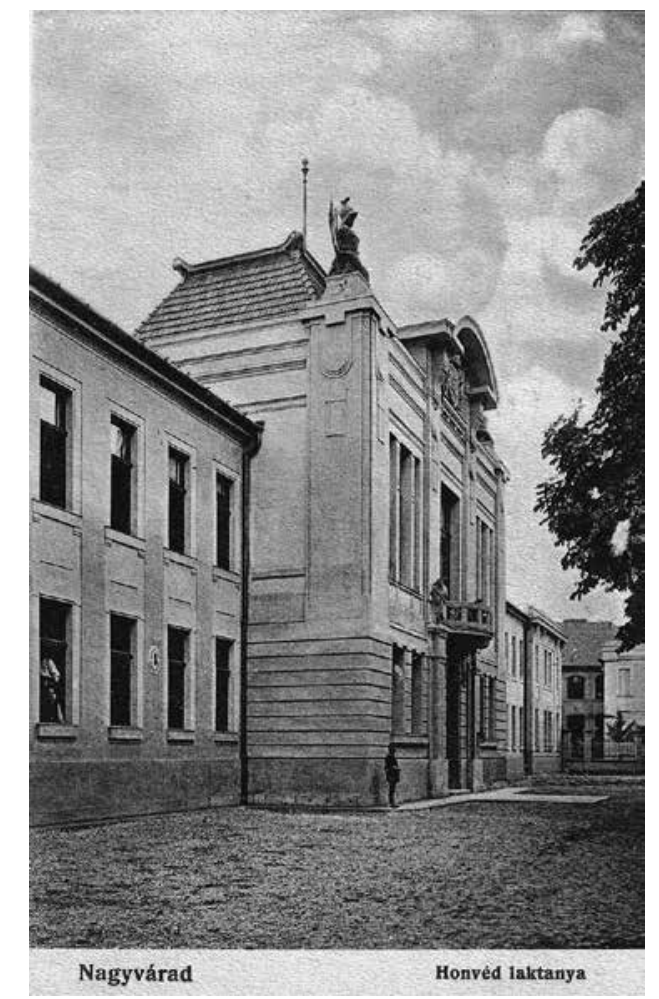

8. ábra. Honvédlaktanya, Nagyvárad, 1902. (képeslap)

\section{AZ ÁLTALA KIVITELEZETT ÉPÜLETEK}

- Neológ zsinagóga. Nagyvárad, Kossuth Lajos utca 22. (ma Strada Independentei). 1878. Romantikus stílusú. Tervező: Busch Dávid, Nagyvárad.

- Iparos menhely (ma lakóház). Nagyvárad, Szacsvay utca 10. (ma Strada Cuza Voda). 1895. Tervezö: Jeney Ernő. 
- Kereskedelmi Csarnok (ma orvosi karok székháza), Nagyvárad, Nagypiacz, később Nagyvásár tér 10. (ma Piața 1 Decembrie). 1894. Tervező: Phann és Gaál, Budapest.

- Színház és bérház, később Uránia-palota, Budapest VIII. Rákóczi (régen Kerepesi) út 21. 1896. Tervező: Schmahl Henrik, Budapest. Kivitelezés Baumann Bernáttal és Kölber Lajossal.

- Szigligeti Színház. Nagyvárad, Bémer tér (Piața Regele Ferdinand I.). 1900. Tervező: Fellner és Helmer, Bécs. Kivitelezés Guttman Józseffel, Rendes Vilmossal és ifj. Rimanóczy Kálmánnal.

- Az id. Rimanóczy-palota, Nagyvárad, Széchenyi tér 1. 1905. Tervező: ifj. Rimanóczy Kálmán.

\section{IFJABB RIMANÓCZY KÁLMÁN (1870. ÁPRILIS 30. - 1912. JÚLIUS 12.)}

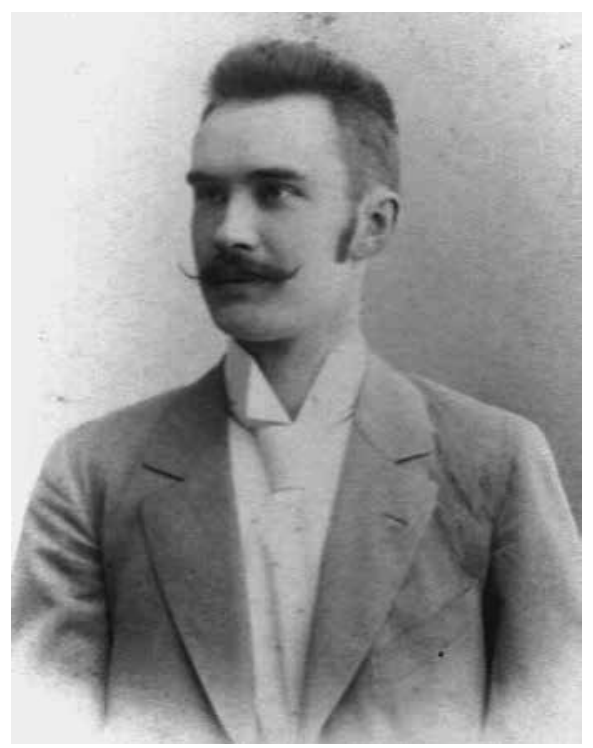

9. ábra. Ifjabb Rimanóczy Kálmán arcképe (Rimanóczy Jenő gyüjteménye)

Ifjabb Rimanóczy Kálmán (9. ábra) Nagyváradon született és szülővárosában végezte elemi iskolai tanulmányait. Középiskolába a helyi szokástól eltérően nem a Premontrei Főgimnáziumba járt, hanem vagy Budapesten, vagy Bécsben. Az 18881889-es tanévben a budapesti Müegyetem beiratkozott hallgatója volt. ${ }^{9}$ Nem tudjuk,

${ }^{9} \mathrm{Az}$ 1888/9-iki tanévben bejegyezve volt hallgatók névsora. A Királyi József-Müegyetem programja az 1889/90. tanévre. A Pesti Lloyd Társulat Könyvnyomdája, Budapest 1889. 42. 


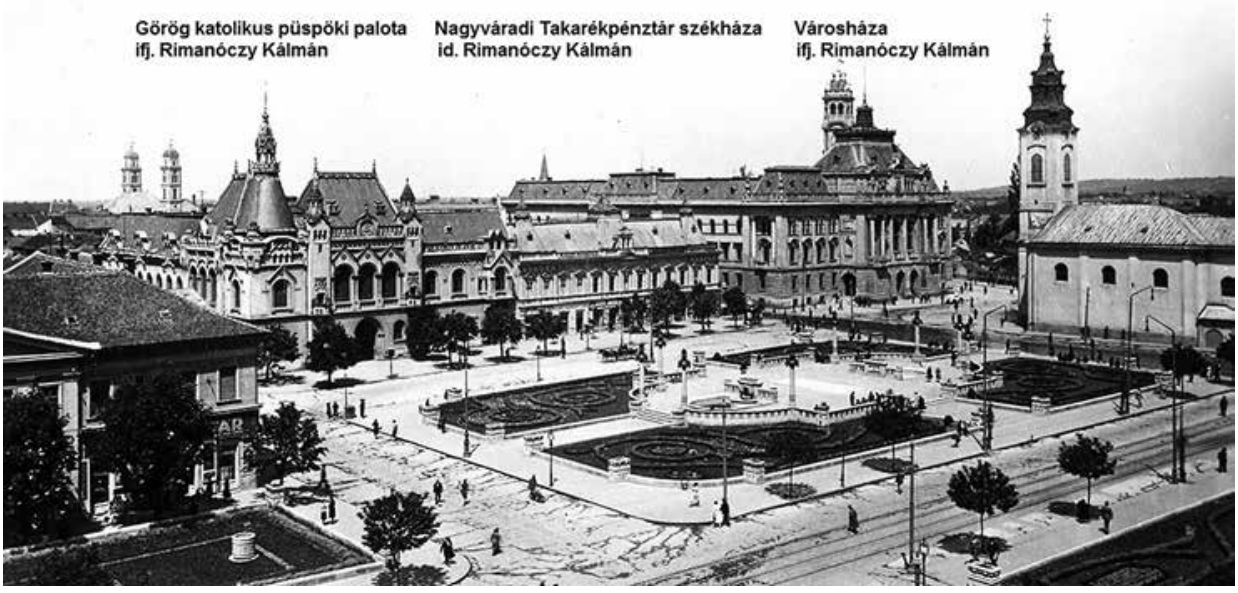

10. ábra. A nagyváradi Szent László-tér épületei, 1887-1905 (képeslap)

mi okból hagyta félbe ottani tanulmányait, hogy azután a híres Berlin-Charlottenburg-i Technische Hochschulén szerezzen 1892-ben építészmérnöki oklevelet. Ezt követöen Budapesten dolgozott Czigler Győző egyetemi tanár irodájában, 1894-ben pedig építőmesteri iparengedélyt szerzett. Ezután Nagyváradon édesapja nagy építkezéseit vezette. Első közös munkájuk a Kereskedelmi Csarnok palotájának építése volt. 1899-től önállóan dolgozott, saját építészeti irodát tartott fenn. Számos országos tervpályázaton díjat nyert. Nagyváradon egymás után valósultak meg a tervei alapján épített közintézmények és paloták, köztük élete legmonumentálisabb alkotása, a nagyváradi városháza épülete. Szakmai pályafutását eklektikus épületekkel kezdte, a századforduló környékén a neoromán és neogót stílussal is kísérletezett, 1900 után azonban elsősorban a német szecesszió, az északi Jugendstil, illetve a korabeli müncheni építészet hatott munkáira (10. ábra).

Édesapja halála után tovább vitte a családi gyárak és építési feladatok ügyeit. Építészi hírneve akkor már túllépte a város határait $\mathrm{A}$ belügyminiszter megbízta a máramarosszigeti elmegyógyintézet tervezésével, majd tervei szerint felépítették a Debreceni Első Takarékpénztár Piac utcai palotáját. Vidéki kastélyokat épített Mezőgyánban (Nagygyanté) gróf Tisza Istvánnak, Biharugrán (Szilaspuszta) Bölöny Józsefnek, Feketebátorban Lovassy Ferencnek, Nagyszénáson a gróf Károlyi családnak és Dobajban dr. Schwartz Istvánnak. Szívének legkedvesebb alkotása azonban a horvát tengerpartra megálmodott Miramare szálloda volt Cirkvenica (ma Crikvenica) strandja mellett. „Remek kilátással, nyitott óriás függőerkéllyel, kávéházzal, étteremmel, saját villanyteleppel, személyszállító, teherszállító emelőgépekkel, külön vízvezetékkel, légfütéssel, minden szoba mellett külön fürdőberendezéssel, minden elképzelhető kényelemmel”- ahogy azt szemtanúként Nagy Márton leírta. ${ }^{10}$

\footnotetext{
${ }^{10}$ Jósa Piroska: Ismerkedés Crikvenicával (Nagyváradi emlékek). Történelmi Magazin 9 (2007) 2. 19-20.
} 
Ifjabb Kálmán nemcsak apja téglagyárát vette át mérnök testvérével (Bélával) és müködtette tovább 1911-től Rimanóczy Kálmán utódai téglagyára Nagyváradon néven, hanem - a korabeli cégjegyzékek tanúsága szerint - önálló vállalkozásokban is részt vett. Mübútor- és parkettagyárat üzemeltetett, melynek városi raktára a Fő utcai (Strada Republicii) Rimanóczy-palotában volt. Résztulajdonosa volt faipari (Élesdi Erdőipar), ingatlanforgalmi (Építési és telek-adásvételi Részvénytársaság), csatornázási (Nagyváradi Általános Csatornázási Vállalat) és kereskedő cégeknek (Bihar megyei tüzifa árusító Rt.). Haláláig tagja volt Nagyvárad város törvényhatósági és közigazgatási bizottságának, az Osztrák-Magyar Bank váltóbíráló bizottságának, valamint az Egyesült Bihar megyei és Központi Takarékpénztár felügyelö bizottságának. Ez időben a Nemzeti Munkapártnak is egyik leglelkesebb vezérharcosa volt.

1903-ban ifj. Rimanóczy Kálmán is megépítette a maga velencei gótikától ihletett emeletes palotáját az Úri (ma Ciorogariu) utca 3. szám alatt, ahová még ugyanabban az évben át is költöztek édesapja Áldás utcai házából fiatal feleségével és három gyermekével. A szinte teljes életét kitöltő megfeszített munka azonban hamar felörölte egészségét, az 1912-es év elején betegeskedni kezdett. Pihenést ajánlottak neki, de a hosszabbra tervezett olaszországi útról állapota rosszabbodása miatt vissza kellett fordulnia. Egy bécsi szanatóriumban hunyt el az év nyarán. Irodáját halála után özvegye, Janky Auguszta és testvére, Rimanóczy Béla vette át, hogy legalább a folyamatban lévő munkákat be tudják fejezni munkatársa, Krause Tivadar segítségével.

\section{IFJ. RIMANÓCZY KÁLMÁN AZONOSÍTOTT MUNKÁI}

- Katolikus Kör (ma az Állami Filharmónia székháza). Nagyvárad, Szilágyi Dezső u. 5. (ma Strada Moscovei). 1895. Historizáló (neobarokk) stílusú. Tervezés és kivitelezés.

- Szent Vince Intézet. Nagyvárad, Nogáll utca 5. (ma Strada Partenie Cosma). 1899, 1911. Neoreneszánsz stílusú. A központi szárny emeletráépítésének tervezése és kivitelezése, illetve öttengelyes bővítés az utcai fronton leányinternátus számára (utóbbi kivitelezője Krause Tivadar).

- Pénzügy-igazgatósági palota (ma poliklinika). Nagyvárad, Fő utca 35. (ma Strada Republicii). Historizáló (neobarokk) stílusú. 1900. Tervezés és kivitelezés (11. ábra).

- Vasútállomás, Nagyvárad, Állomás tér (ma Piaţa Bucureşti). 1902. Historizáló stílusú. Az 1857-ben épült romantikus pályaudvar átépítése. Tervezés, illetve kivitelezés Rendes Vilmossal.

- Városháza. Nagyvárad, Szent László tér 1. (ma Piața Unirii). Tervpályázat 1896. Tervezés: 1898. Kivitelezés: 1903. Historizáló (neoreneszánsz) stílusú. Tervezés és kivitelezés (12. ábra). 


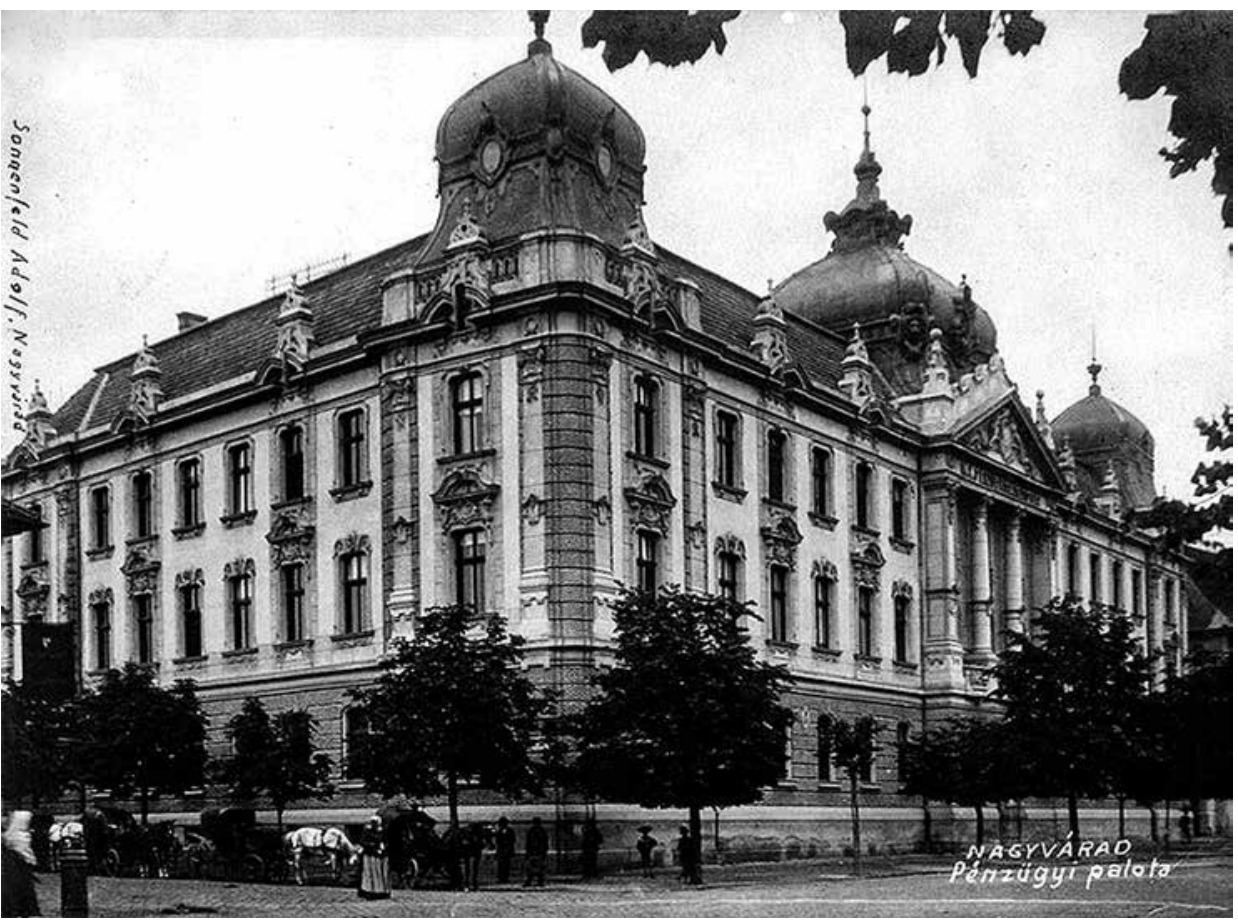

11. ábra. A Pénzügyigazgatóság palotája, Nagyvárad, 1900 (képeslap)

- A Budapest VIII. Kerepesi (ma Rákóczi) út 21. számú épület színháztermének átépítése az Uránia Tudományos Társaság számára. 1899. Tervezés. Kivitelező: Szabó János.

- Evangélikus templom. Nagyvárad, Körös utca 28. (ma Strada Tudor Vladimirescu). 1903. Neogót stílusú. Kivitelezés. Tervező: Pecz Samu, Budapest.

- Ifj. Rimanóczy-palota (ma az Ortodox Püspökség székhelye). Nagyvárad, Úri utca 3. (ma Strada Ciorogariu). 1903. Historizáló (neogót) stílusú. Tervezés és kivitelezés.

- Ideg- és elmegyógyintézet. Nagyvárad, Kórház utca 26. (ma Strada Louis Pasteur). 1902-1904. Főépület és kilenc pavilon historizáló stílusban, szecessziós részletekkel. Tervezés és kivitelezés.

- Komlós-ház. Nagyvárad, Korona utca 28. (ma Strada George Enescu). 1903. Historizáló szecessziós elemekkel.

- Az Olaszi Szentlélek Kiáradása római katolikus plébániatemplom újraépítése. Nagyvárad, Sal Ferenc utca 1. (ma Strada Dunărea) és Fő utca 28. (ma Strada Republicii) sarkán. 1901-1905. Neobarokk, erős manierista stíluselemekkel. Tervezés és kivitelezés. 


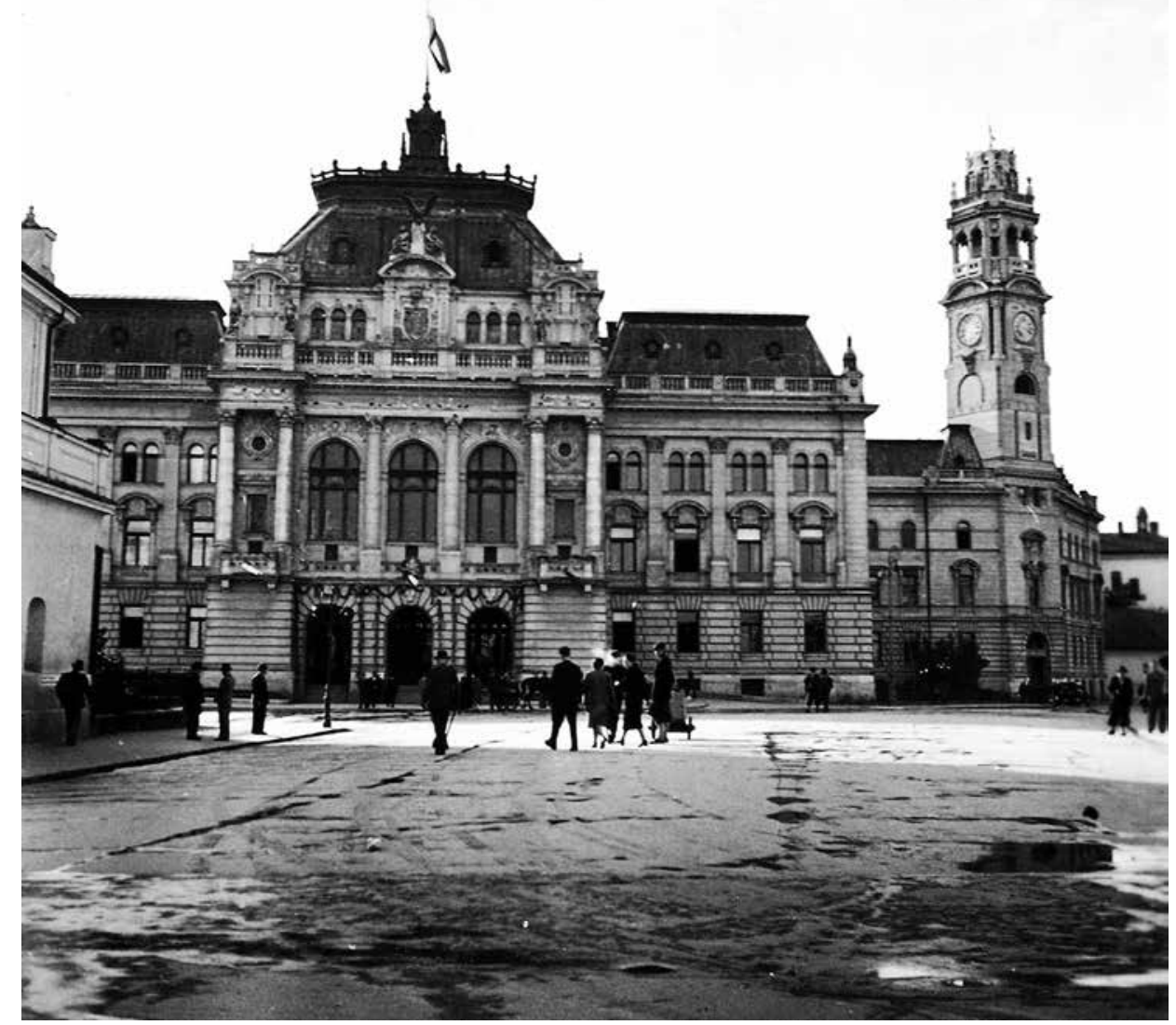

12. ábra. A nagyváradi Városháza (1903) képe 1940-ben (Fortepan 76956. Klenner Aladár)

- Görög katolikus püspöki palota. Nagyvárad, Szent László tér 3. (ma Piața Unirii) és Pável utca (ma Strada Episcop Mihai Pavel) sarkán. 1903-1905. Historizáló (bizáncias vonásokat is tartalmazó neoromán) stílus. Tervezés és kivitelezés.

- LovassyFerenc kastélya,Feketebátor(Batăr), Biharmegye. Helye:4642’31.7”'N, 2145’25.6” E. 1903 körül. Historizáló stílusú. Tervezés és kivitelezés. ${ }^{11}$

- Görög katolikus püspöki lak. Belényes (ma Beius) Bihar megye. 1905 körül. Historizáló stílusú.

- Lakóház. Nagyvárad, Úri utca 23. (ma Str. Ciorogariu). 1905 körül (Gerle János feltételezése). Szecessziós.

${ }^{11}$ Borsi Balázs: Örökségünk eladó. Biharország 2014. február 4. http://muemlekem.hu/hatareset/Lovassykastely-Feketebator-2871 (Utolsó megtekintés: 2017. 03. 09.) 


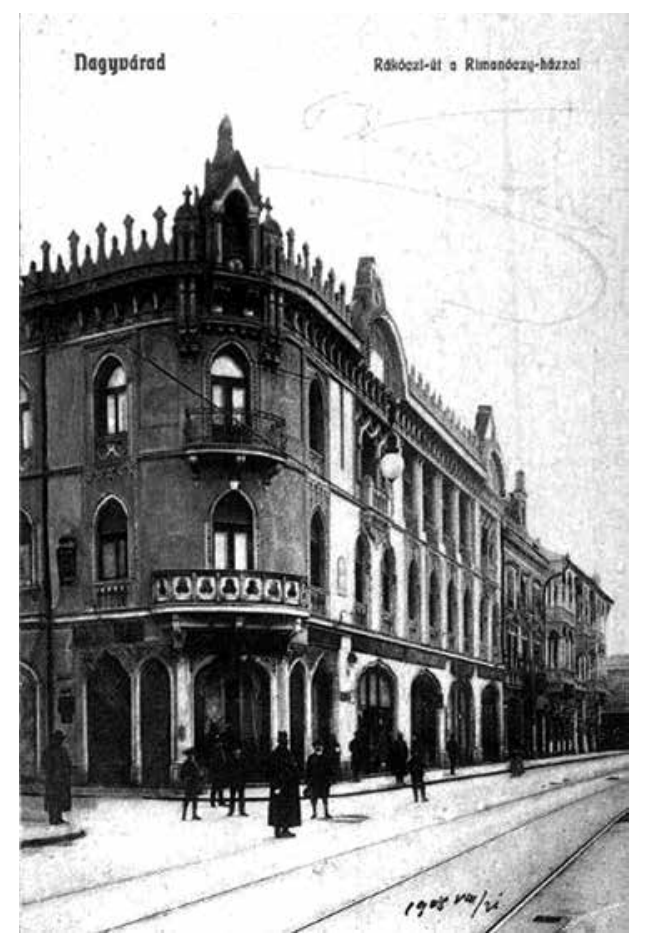

13. ábra. Idősebb Rimanóczy Kálmán háza, Nagyvárad, 1905 (képeslap)

- Id. Rimanóczy-palota. Nagyvárad, Széchenyi tér 1. (ma Parcul Traian) és Fő utca (ma Strada Republicii) sarkán. 1905. Historizáló (neogót). Tervezés (kivitelezte az édesapja) (13. ábra).

- Várnai-villa. Nagyvárad, Ezredévi emléktér 30. (ma Piata Libertătii). 1905. Szecessziós stílusú. Tervezés.

- Stern-palota. Nagyvárad, Fő utca 10. és 10.A (ma Strada Republicii). 19041905. Szecessziós stílusú. Komor Marcell és Jakab Dezső tervének átdolgozása és kivitelezése Rendes Vilmossal közösen.

- Moskovits Miksa palotája. Nagyvárad, Széchenyi tér 4. (ma Parcul Traian). 1905. Szecessziós stílusú. Tervezés és kivitelezés (14. ábra).

- Hotel Miramare (gyógyszálló), Cirkvenica (ma Crikvenica, Horvátország, 51 Strossmayerovo šetalište -2 ulica bana Jelačića). 1905. Tervezés és kivitelezés. Ma üresen és romosan várja felújítását.

- Bihar Megyei Gazdasági Egylet székhelye (később tüdőszürő intézet). Nagyvárad, Bunyitai Vince-liget (ma Strada Ion C. Brațianu 3.). 1906. Historizáló. Tervezés és kivitelezés.

- Máramaros vármegye elmegyógyintézete, Máramarossziget, Strada Avram Iancu 22. 1906 (15. ábra). 


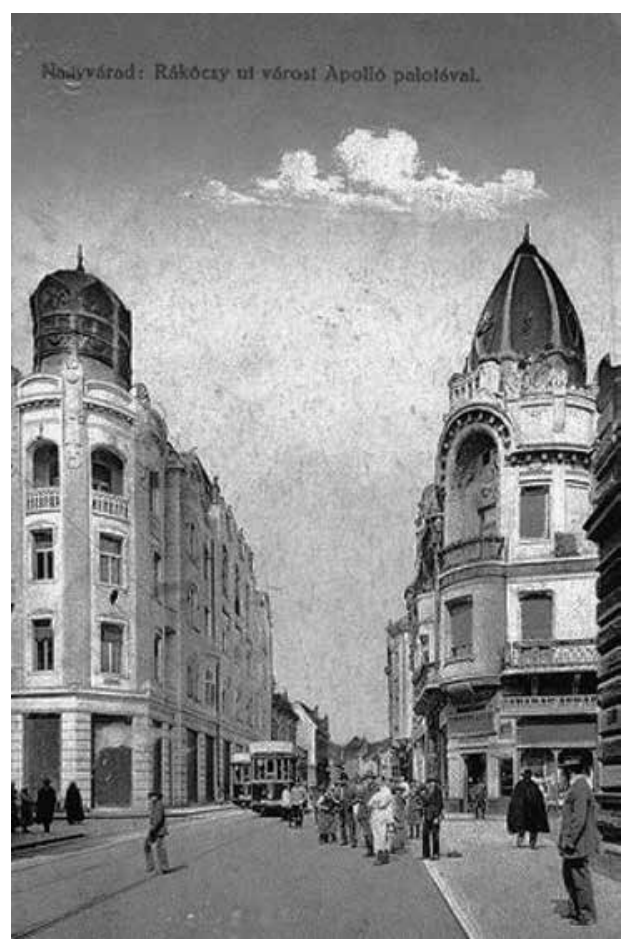

14. ábra. A Moskovitz- és Apolló-paloták, Nagyvárad, 1905, 1911-14

- Nagyváradi Központi Takarékpénztár épülete. Nagyvárad, Bémer tér 4. (ma Piața Regele Ferdinand I.). 1907. Szecessziós stílusú. Tervezés és kivitelezés (16. ábra).

- Lakóház, Nagyvárad, Szalárdi utca 11. (ma Strada George Coşbuc). 1908 körül (Gerle János feltételezése). Szecessziós stílusú.

- Ügyvédi Kamara székháza. Nagyvárad, Korona utca 1. (később Ritoók Zsigmond, ma Strada George Enescu). 1909. Szecessziós stílusú. Tervezés. Kivitelezte Reisinger József.

- Népszanatórium terve, Nagyvárad (ingyen készítette!). Népszava 1909. X. 14.

- A múzeum bővítése. Nagyvárad, Múzeum utca 2. (ma Strada Muzeului). 1910. Historizáló (neoreneszánsz) stílusú. Tervezés és kivitelezés.

- Darvasy-ház, Nagyvárad, Fő utca 75. (ma Strada Republicii). 1910. Tervezés. Kivitelezö: Tarr György. Szép, ólmozott üvegablakokkal.

- Lakóház, Szent János (ma Ady Endre) utca 3. 1911. Elpusztult.

- Csendörségi iskola. Nagyvárad, Rulikowski utca 5. 1911-1913. Az asztalosmunkák kivitelezője. Tervező: Vágó József.

- Bölöny-ház. Nagyvárad, Szaniszló utca 5. (ma Strada Mihai Eminescu). 1912. Visszafogott szecessziós stílusú. Tervezés és kivitelezés. 


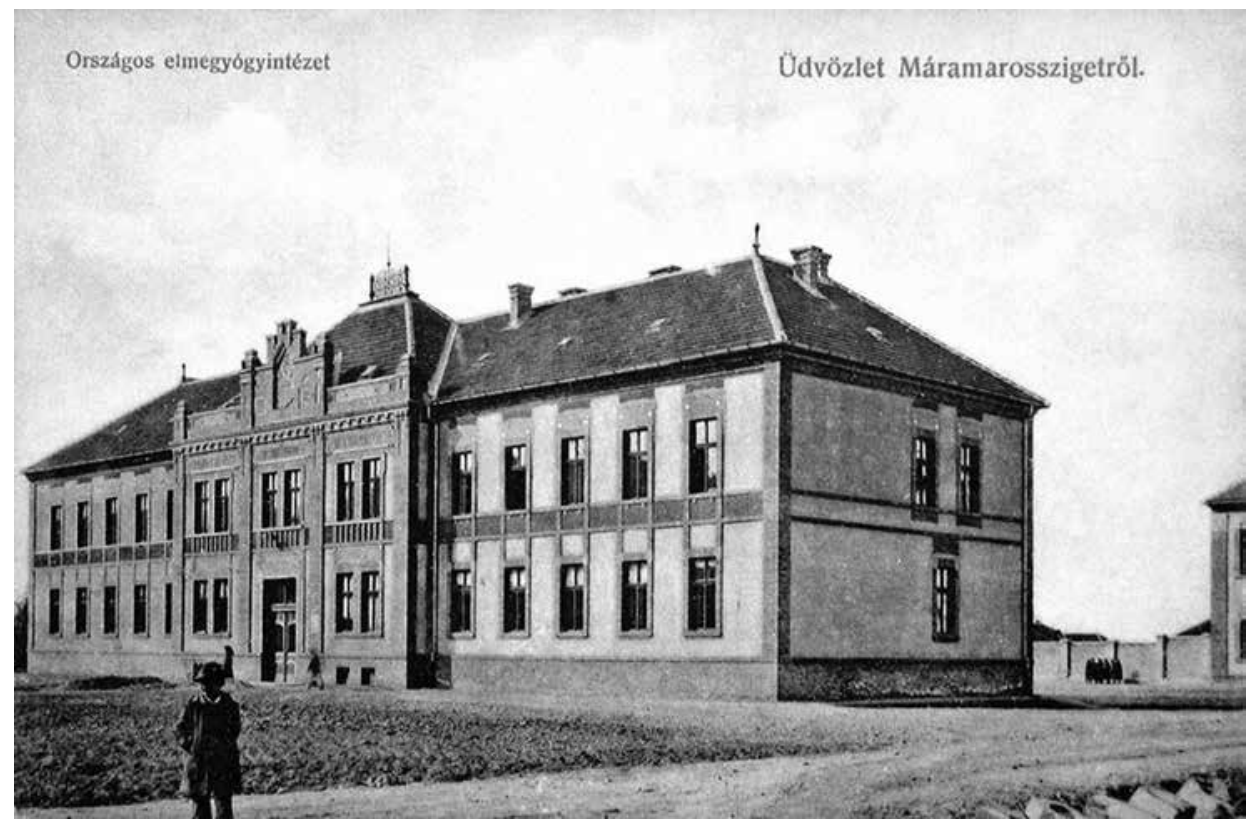

15. ábra. Elmegyógyintézet, Máramaros, 1906 (képeslap)

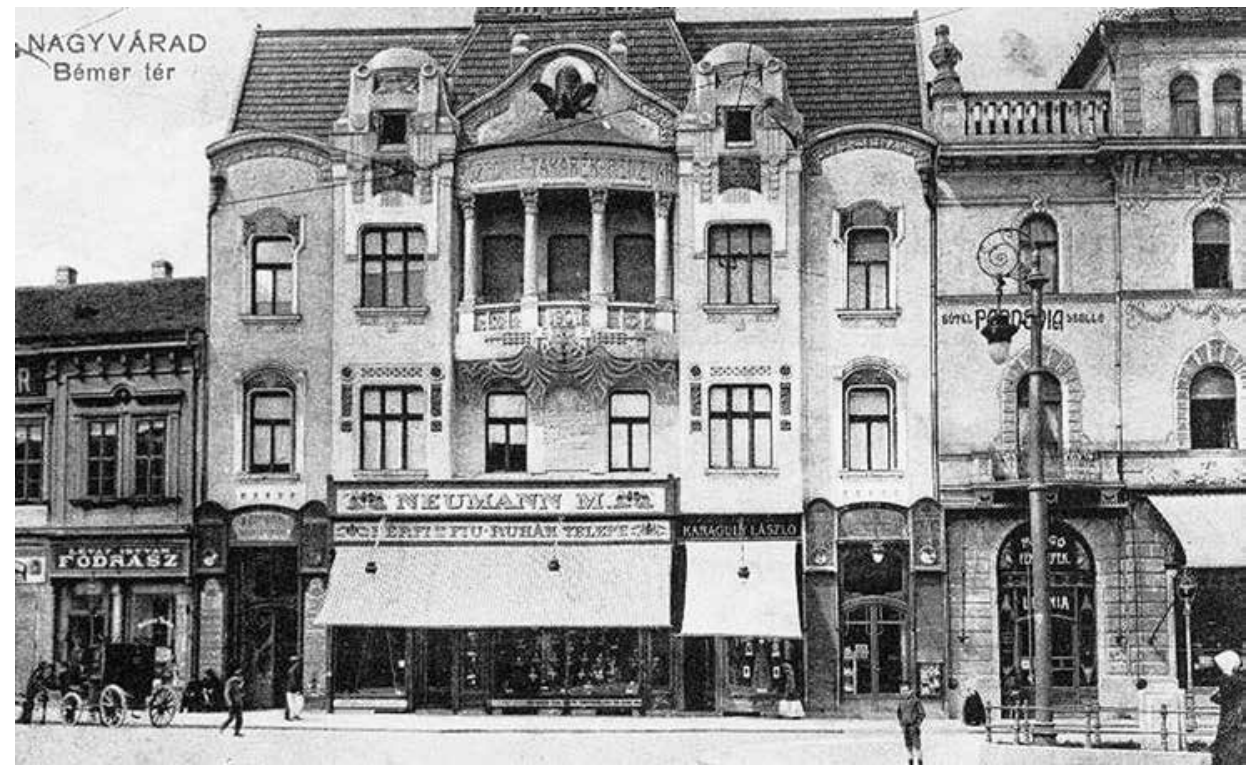

16. ábra. A nagyváradi Központi Takarékpénztár épülete. Nagyvárad, 1907 (képeslap) 
- Debreceni Első Takarékpénztár, Debrecen, Piac utca 22-24. 1912.

- Apolló-palota. Nagyvárad, Fő utca 12. (ma Strada Republicii). 1911-1914. (Rimanóczy halála után a kivitelezést befejezte Krause Tivadar. Gazdag szecessziós stílusú (14. ábra).

\section{RIMANÓCZY ÁRPÁD (1867. MÁRCIUS 17. - 1925. FEBRUÁR 2.)}

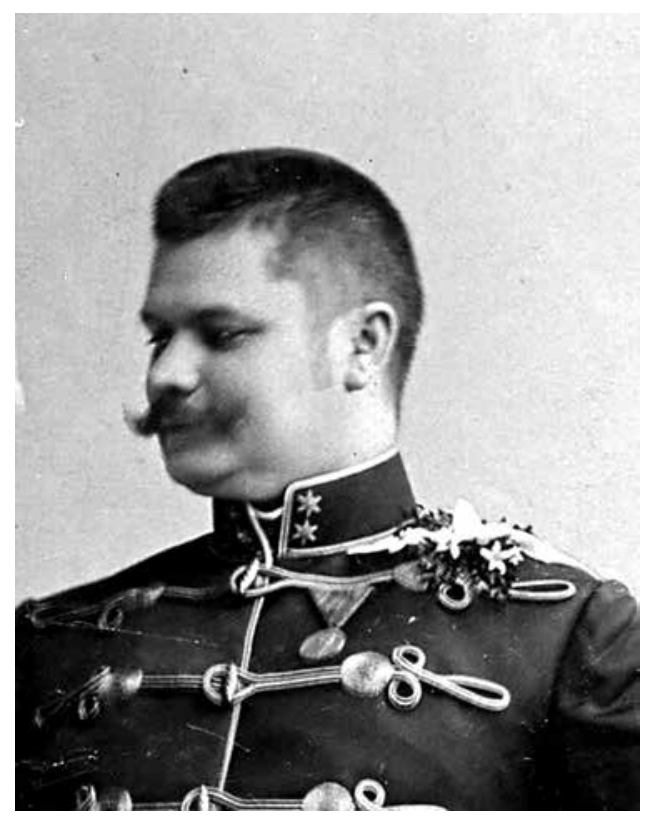

17. ábra. Rimanóczy Árpád arcképe (Rimanóczy Jenő gyűjteménye)

Idősebb Rimanóczy Kálmán elsőszülött fia - mint láttuk - édesanyjánál nevelkedett Budapesten. Amikor az asszony férje 1870-ben válópert kezdeményezett, mert felesége ismét elhagyta, nem vállalta tovább Árpád Eduárd nevelését. Ezért vélhetően ügyvédi segítséggel azt a megoldást találták ki, hogy a Gömöry Herminával élő salamonfai Rimanóczy Károly (1817-1893) - aki a család soproni ágához tartozott - „névleg” adoptálja Árpádot. Az adoptálás tényét talán az is igazolja, hogy Rimanóczy Árpád felnőttként salamonfai rimanóczi Rimanóczy Árpádként kezdte magát és utódait is megnevezni, és a Farkasréti temetőben állott sírkövén is a salamonfai elönév szerepelt vezetékneve elött. Később, nem tudjuk, pontosan mikor, id. Rimanóczy Kálmán magához vehette Árpádot. 1889-ben már dokumentáltan Nagyváradon tartózkodott (17. ábra).

Több forrás szerint a reáliskola után a Mủegyetemen végzett építészként, ám a Mủegyetemre beiratkozott hallgatók listáján a neve egyetlen évben sem szerepel. Az 
viszont biztos, hogy 1890. április 26-án, rendes sorozáson, a Magyar Királyi Nagyváradi 4. Honvéd gyalogezredhez vonult be, majd a lovassághoz került, ahol egyéves önkéntes szolgálat után 1892 végén kapott tartalékos hadnagyi kinevezést. ${ }^{12}$ 1892-1895 között hadnagyi rangban szolgált az 1. sz. huszárezrednél. Ezután tartósan a budapesti I. honvédkerületi parancsnokságra vezényelték, ahol 1898-tól főhadnagyi rangban az építési osztály munkatársa, majd - miután 1902-1903-ban Bécsben elvégezte a katonai építőmérnöki tanfolyamot (Militär-Bau- Ingenieur-Curs) - 1908tól immár századosként osztályfönöke lett. 1909-ben a honvédelmi miniszter többek között Rimanóczy Árpádot is delegálta a főváros tanácsa által, katonai építési ügyek elbírálására létesített vegyes bizottságba. ${ }^{13}$ 1914-ben mérnökkari őrnaggyá, 1918-ban alezredessé léptették elő. A háború alatt teljesített kiváló szolgálata elismeréséül 1916-ban a Ferencz József-rend lovagkeresztjét kapta, 1918-ban pedig a háború alatt a katonai egészségügy körül szerzett kiváló érdemeit ismerték el a Vörös Kereszt hadiékitményes II. oszt. díszjelvénnyel.

1918-ban húszéves szolgálati és tízéves főnöki jubileumára munkatársaitól díszes faragott fadobozt kapott ajándékba. ${ }^{14}$ 1920-ban gazdasági tanácsos címet kapott a minisztertanácstól, s kinevezték a Pénzügyminisztérium XVII. c (volt katonai épületeket kezelö) osztályának vezető tanácsosává. Huszonöt éves jubileuma alkalmából (1923-ban) az osztály dolgozói által indított gyüjtés eredményeképpen és Rimanóczy Árpád 75 ezer koronás adományával kiegészítve a királyi József müegyetem hallgatói javára 100000 korona értékpapír tőkével tettek alapítványt. ${ }^{15}$ Abban az évben vonulhatott nyugdíjba ezredesi rangban. Egyes adatok szerint 1922-ben a Honvédelmi Minisztérium XI. osztályának vezetője volt főtanácsosi beosztásban. ${ }^{16}$

Rimanóczy Árpád a századforduló táján ismerkedett meg a lengyel származású Zofia Markowskával (Markowski Zsófia Mária), a híres lengyel szobrász, Julian Markowski lányával. Arról nincs tudomásunk, hogy először Lengyelországban vagy Magyarországon találkoztak. Polgári esküvőjük mindenesetre Budapesten volt 1901. július 20-án. Egy évvel később Árpádot Bécsbe küldték katonai mérnöki tanfolyamra, ahová magával vitte feleségét is. Ott született Gyula (1903) és János (1904) fia, harmadik gyermekük, László (1907) azonban már Budapesten látta meg a napvilágot Lógody utcai lakásukban. 1912-ben költöznek át a Gellérthegyre, a Rimanóczy Árpád által tervezett kétlakásos villába (XI. Berényi utca 4/a) (18. ábra). Eddig ez volt egyetlen ismert építészeti terve, ám nekrológjában egy-két katonai munkájára is találunk utalást: „Nevéhez és munkásságához úgy a fóvárosi,

\footnotetext{
${ }^{12}$ Budapesti Hirlap 1892. december 30. 7.

${ }^{13}$ Fövárosi Közlöny 1909. 17. sz. 343.

${ }^{14}$ A gyöngyöshalászi Takách Béla által tervezett és Nagy József, illetve Ullmann Frigyes szobrászok által kivitelezett míves doboz képét a Magyar Iparmüvészet folyóirat közölte az 1918. évfolyamában (132. o.).

${ }^{15}$ Hivatalos Közlöny (1923) 13. 202.

${ }^{16}$ Apáthy László százados vallomása 1922. július 14-én. In: Zsiga Tibor: Burgenland vagy NyugatMagyarország? Oberwart 1991. Internetes változata: http://www.sulinet.hu/oroksegtar/data/kulhoni_magyarsag/2010/a/burgenland_vagy_nyugat_magyarorszag/pages/bvnym_07_elokeszuletek.htm. (Utolsó megtekintés: 2017.03. 09.)
} 
mint vidéki monumentális építkezések egész sora füződik. Az ő tervei szerint építették a kecskeméti huszárlaktanyát, a berettyóújfalusi és salgótarjáni kaszárnyát, de a fővárosban is számos építkezés tervezője volt." ${ }^{17}$ Utóbbiakra további kutatás deríthet majd fényt. Saját háza ma is áll, kissé átalakított formában, vakolatdíszek és szép télikert ablaka nélkül.

A világháború után több vállalkozásban is részt vett. Elsőként a Hadianyagértékesítő, majd 1920-tól Anyagértékesítő Intézet Rt. igazgatósági tagja lett. A használaton kívül került Daróczi utcai katonai raktárak címén jegyezték be 1921-ben a Kelenföldi Faipari és Építő Rt.-t, melyben Rimanóczy egykori katonatársaival szövetkezett a „kelenföldi építő- és faipar előmozdítására, építő ipari vállalkozásra és az építőiparral kapcsolatos kereskedelmi ügyletekre és gyáripar üzésére". ${ }^{18}$ Ugyanaz az ingatlan volt a székhelye az Amica Ecetipari Rt.-nek (1922) és a Kelenföldi Posztógyár Részvénytársaságnak (1922), melyeknek ugyancsak igazgatósági tagja volt. Ezenkívül még néhány más helyen müködő kereskedelmi és iparvállalatban töltött be hasonló tisztséget. Civil múködését és nyugdíjas éveit nem sokáig élvezhette, súlyos cukorbaja következtében 1925 elején meghalt, viszonylag fiatalon, mindössze ötvennyolc éves korában.

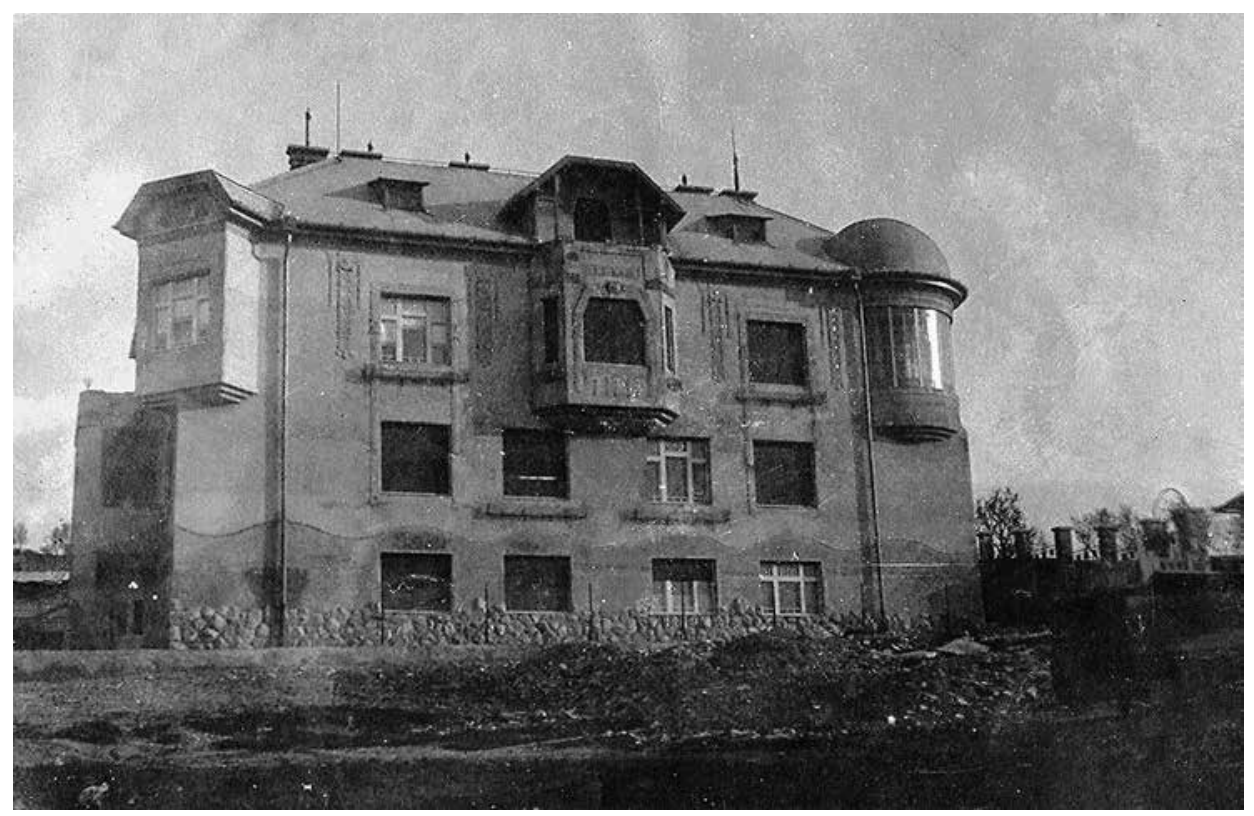

18. ábra. Kétlakásos villa a Gellérthegyen, Budapest, 1911-1912 (Rimanóczy Jenő gyűjteménye)

\footnotetext{
${ }^{17}$ Nekrológ. 8 órai újság 1925. február 5. 6. o.
}

${ }^{18}$ Központi Értesitö (1922) 23. 485. 


\title{
VÁLOGATOTT IRODALOM
}

Gerle János - Kovács Attila - Makovecz Imre: A századforduló magyar épitészete. Szépirodalmi Könyvkiadó - Bonex, Budapest 1990. 168-169, 261-262.

Jósa Piroska: Emlékezés a váradi Rimanóczy családra. Mellékletek a Váradi püspökség levéltárából. In: Bihari sorsok a változó időben. (Partiumi füzetek 51.) Szerk.: Jósa Piroska. Nagyvárad 2008. 144-155.

Péter I. Zoltán: A két Rimanóczy. In: Városok és Mühelyek a századfordulón. Konferencia a kiegyezés utáni magyar épitészetröl. 1867-1914. Ernst Múzeum, Budapest 2000.

Péter I. Zoltán: A két Rimanóczy. Országépitö 11 (2000) 4. 33-35.

Péter I. Zoltán: A két Rimanóczy. Partium 7 (2000) 2. 8-9.

Péter I. Zoltán: Nagyvárad 900 éves múltja és épitett öröksége. Noran Könyvkiadó, Budapest 2005.

Péter I. Zoltán: Ifj. Rimanóczy Kálmán szakmai hitvallása. Emlékezés a jeles mủépítészre halálának 100. évfordulóján. Várad 11 (2012) 7. http://www.varad.ro/ifj-rimanoczy-kalman-szakmai-hitvallasa/ (Utolsó megtekintés: 2017. 03. 09.)

Péter I. Zoltán: A két Rimanóczy. A nagyváradi városkép alakitói. Riport Kiadó - Várad folyóirat, Nagyvárad 2013.

Péter I. Zoltán: Egy tehetséges és sikeres építészdinasztia. Várad 14 (2015) 6.

\section{HISTORY OF THE RIMANÓCZY ARCHITECT DYNASTY}

\author{
PART I. THE BRANCH OF FAMILY IN NAGYVÁRAD
}

\begin{abstract}
Summary
Of many important architect dynasties comprising several generations, the Rimanóczy family is preeminent since it contributed to the development of Hungarian architecture with the work of four succeeding generations from the Austrian-Hungarian Compromise of 1867 to the fall of the communist regime in 1989. The founding father, Kálmán Rimanóczy Senior, who was a master builder and his son, Kálmán Rimanóczy Junior, a graduate of the Berlin-Charlottenburg Polytechnics, both practiced in a country town, Nagyvárad (Oradea now in Romania), which underwent a fundamental process of modernization and urbanization in the last two decades of the 19th century. They took a prominent part in the transformation of the city centre by designing or realizing key buildings that still determine the cityscape. Árpád Rimanóczy, the first son of Kálmán Senior, joined the Army and after having graduated from the Vienna Military Engineering Course worked for the Building Department of the Ministry of Defence in Budapest. His elder son, Gyula continued the profession and his distinguished life-work spanning the 1920 s and 1950s is no doubt the most well-known of the whole family. His two sons, Gyula Junior and Jenö followed the line, their activity fell almost completely on the period of state project offices (they were employed by the municipal office BUVÁTI and a specialized office for industrial buildings IPARTERV, respectively). The history of the dynasty was compiled by the youngest member, Jenö Rimanóczy, based on surviving documents and memories, as well as the most important publications. This is the first part of a three-piece series, which sheds light on the less-known first two generations of the family.
\end{abstract}

Keywords: Rimanóczy-dynasty, history of architecture, $19^{\text {th }}-20^{\text {th }}$ century, Nagyvárad, Budapest 